\title{
Fluctuating role of antimicrobial peptide hCAP18/LL-37 in oral tongue dysplasia and carcinoma
}

\author{
MARLENE VIERTHALER ${ }^{1-4^{*}}$, PRISCILA CAMPIONI RODRIGUES ${ }^{1,2^{*}}$, ELIAS SUNDQUIST $^{1,2}$, \\ MARIA SIPONEN ${ }^{5,6}$, TUULA SALO ${ }^{1,2,7,8}$ and MAIJA RISTELI ${ }^{1,2}$ \\ ${ }^{1}$ Cancer Research and Translational Medicine Research Unit, Faculty of Medicine; \\ ${ }^{2}$ Medical Research Center Oulu, Oulu University Hospital, University of Oulu, FI-90014 Oulu, Finland; \\ ${ }^{3}$ Skin Cancer Unit, German Cancer Research Center (DKFZ), D-69120 Heidelberg; Department of Dermatology, \\ Venereology and Allergology, University Medical Center Mannheim, Ruprecht Karl University of Heidelberg, \\ D-69117 Heidelberg; ${ }^{4}$ Center for Molecular Biology of Inflammation, Institute of Medical Biochemistry, \\ University of Muenster, D-48149 Muenster, Germany; ${ }^{5}$ Institute of Dentistry, University of Eastern Finland, FI-70211; \\ ${ }^{6}$ Oral Health Teaching Clinic, Kuopio University Hospital, FI-70029 Kuopio; ${ }^{7}$ Department of Oral and Maxillofacial Diseases, \\ University of Helsinki, and Helsinki University Central Hospital, FI-00014; ${ }^{8}$ HUSLAB, Department of Pathology, \\ Helsinki University Central Hospital, University of Helsinki, FI-00029 Helsinki, Finland
}

Received November 15, 2019; Accepted April 13, 2020

DOI: $10.3892 /$ or.2020.7609

\begin{abstract}
Oral tongue squamous cell carcinoma (OTSCC), the most common cancer in the oral cavity, is aggressive and its incidence is increasing globally. Human host defense cationic antimicrobial peptide-18/antimicrobial peptide leucine-leucine-37 (hCAP18/LL-37) plays a complex role in various types of cancers. In the present study, we characterized the effects of exogenous LL-37 on three OTSCC cell lines and determined the expression of hCAP18/LL-37 in oral dysplastic and OTSCC patient samples. Our data revealed that LL-37, especially in high doses, mostly reduced the proliferation of OTSCC cells, but the effect was fluctuating. However, LL-37 stimulated the migration and invasion of OTSCC cells. The high dose of LL-37 also increased the amount of total epidermal growth factor receptor (EGFR) probably due to stabilization of the receptor to the plasma membrane. However, activation of EGFR downstream pathways was mostly decreased. Our immunohistochemical analysis showed that the hCAP18/LL-37 expression was higher in normal/mild dysplasia than in moderate/severe dysplasia and OTSCC. The hCAP18/LL-37 expression did not correlate with clinicopathological features or outcome of OTSCC patients. Our data
\end{abstract}

Correspondence to: Dr Maija Risteli, Cancer Research and Translational Medicine Research Unit, Faculty of Medicine, University of Oulu, P.O. Box 8000, FI-90014 Oulu, Finland

E-mail: maija.risteli@oulu.fi

*Contributed equally

Key words: oral tongue cancer, hCAP18/LL-37, invasion, proliferation, epidermal growth factor receptor suggest that LL-37 has a fluctuating effect on proliferation, migration and invasion of OTSCC cells, but it does not seem to play a role in the progression of OTSCC.

\section{Introduction}

Oral tongue squamous cell carcinoma (OTSCC) is the most common malignancy in the oral cavity and shows an aggressive clinical behavior with high invasiveness and metastasis rates (1-3). The GLOBOCAN database 2018 estimated 354,864 new cases of oral cancer (including lip cancer) globally (4). Despite constant improvements in strategies for detecting and treating cancers, the survival rates of OTSCC patients remain dismal (5) and globally lip and oral cancers caused approximately 177,384 deaths in 2018 (4). To improve patient diagnostics and treatment, prediction of cancer metastasis and understanding of the factors promoting or inhibiting cancer cell invasion are paramount.

Cathelicidins are a family of vertebrate host defence peptides, but in humans only human cationic antimicrobial protein 18 (hCAP18) has been identified (6-10), which is proteolytically processed to active leucine-leucine-37 (LL-37) $(11,12)$. hCAP18/LL-37 is widely expressed in epithelial and immune cells, shows potent antimicrobial activities against various pathogens and has essential functions in inflammation and modulation of the immune system (6-10). In addition, human host defense cationic antimicrobial peptide-18/antimicrobial peptide LL-37 (hCAP18/LL-37) plays a complex role in carcinogenesis and its overexpression has been implicated in the progression of ovarian, breast, pancreas, prostate and lung cancers, as well as in malignant melanoma (13-18). On the other hand, it has been shown to suppress tumorigenesis in gastric, oral and haematological cancer (19-21). Based on these findings, the effect of LL-37 on cancer seems to depend on the origin and type of the cancer (7). 
LL-37-induced effects on host cells are mediated via specific activation of various cell surface receptors, membrane channels or intracellular targets as well as through an interaction between the cell membrane $(9,10)$. LL-37 has been linked to the activation of $N$-formyl peptide receptor 2 (FPR2) (10,18,22-24), ERBB2 (25), purinergic receptor P2X7R (18) and transactivation of epidermal growth factor receptor (EGFR) $(15,26,27)$. Although LL-37 has been linked to multiple receptors, this mechanism may not explain all of its complex functions in activating or inhibiting cellular responses.

The hCAP18/LL-37 is present in normal human oral mucosa and tongue at transcriptional and protein levels $(28,29)$. Recently, hCAP18/LL-37 was found to be weakly expressed in poorly differentiated oral squamous cell carcinoma (OSCC) relative to normal oral mucosa. The low expression of hCAP18/LL-37 was also related to lymph node metastasis and tumor progression (21). Nonetheless, the role of hCAP18/LL-37 in OTSCC is still unclear. The present study aimed to determine the expression of hCAP18/LL-37 in OTSCC cell lines and tissues and in dysplastic samples of oral tongue. We also characterized the effects of exogenous LL-37 on proliferation, migration and invasion of three OTSCC cell lines. Furthermore, we determined the activation of epidermal growth factor receptor (EGFR), the mitogen-activated protein (MAP) kinase cascade and the PI3K/Akt pathway following LL-7 treatment.

\section{Materials and methods}

Cell culture. The three human OTSCC cell lines HSC-3 [Japanese Collection of Research Bioresources (JCRB) Cell Bank, Osaka, Japan, JCRB0623], SCC-25 (ATCC, Wesel, Germany, CRL-1628) and SAS (JCRB Cell Bank, JCRB0260) were all cultured in 1:1 Dulbecco's modified Eagle's Medium (DMEM)/Ham's Nutrient Mixture F-12 (Gibco; Thermo Fisher Scientific, Inc.) supplemented with $10 \%$ heat-inactivated FBS (Gibco; Thermo Fisher Scientific, Inc.), $100 \mathrm{U} / \mathrm{ml}$ penicillin, $100 \mu \mathrm{g} / \mathrm{ml}$ streptomycin, $50 \mu \mathrm{g} / \mathrm{ml}$ ascorbic acid, $250 \mathrm{ng} / \mathrm{ml}$ amphotericin B and $0.4 \mathrm{ng} / \mathrm{ml}$ hydrocortisone (all from Sigma Aldrich; Merck KGaA). Human papillomavirus HPV16 immortalized human oral epithelial cells (IHGK) (30) were cultured in Keratinocyte-SFM (Gibco; Thermo Fisher Scientific, Inc.) supplemented with $5 \mathrm{ng} / \mathrm{ml}$ human recombinant epidermal growth factor (EGF 1-53) (Gibco; Thermo Fisher Scientific, Inc.), $50 \mu \mathrm{g} / \mathrm{ml}$ bovine pituitary extract (Gibco; Thermo Fisher Scientific, Inc.), $100 \mathrm{U} / \mathrm{ml}$ penicillin, $100 \mu \mathrm{g} / \mathrm{ml}$ streptomycin, $250 \mathrm{ng} / \mathrm{ml}$ amphotericin $\mathrm{B}$ and $100 \mu \mathrm{M} \mathrm{CaCl}$ (all from Sigma Aldrich; Merck KGaA). All cells were maintained at $37^{\circ} \mathrm{C}$ with $5 \% \mathrm{CO}_{2}$. Cells were regularly mycoplasma tested with EZ-PCR Mycoplasma test kit (Biological Industries, Beit-Haemek, Israel).

BrdU proliferation assay. The cells were seeded in normal culture media on 96-well culture plates at a density of 5,000 cells/well in quintuplicate. After $24 \mathrm{~h}$ the compound $100 \mathrm{ng} / \mathrm{ml}$ EGF (positive control) (ProSpec) or 0.5, 1.0, 5.0, 10.0 or $50.0 \mu \mathrm{g} / \mathrm{ml} \mathrm{LL}-37$ (Isca Biochemicals) was added to the cells. The cell proliferation was determined using the Cell Proliferation ELISA BrdU (cat. no. 11647229001, Roche) according to the manufacturer's protocol after 24, 48 and $72 \mathrm{~h}$. Absorbance was measured at $450 \mathrm{~nm}$ using the Victor2 Microplate Reader (Perkin Elmer Wallac). Media-only containing wells were measured as a blank control. The results represent the average of four separate experiments.

TUNEL cell death detection. The HSC-3 cells were seeded in normal media on an 8-well Lab-Tek ${ }^{\circledR}$ Chamber Slide ${ }^{\mathrm{TM}}$ System (Nalge Nunc International) at a density of 12,500 cells/well in duplicate. After $24 \mathrm{~h}$ the compound $100 \mathrm{ng} / \mathrm{ml}$ EGF (positive control) (ProSpec) or $50 \mu \mathrm{g} / \mathrm{ml}$ LL-37 (Isca Biochemicals) was added to the cells. After $48 \mathrm{~h}$, DNA fragmentation was determined using the In situ Cell Death Detection Kit, Fluorescein (Roche) according to the manufacturer's protocol. Cells were mounted with VECTASHIELD Antifade Mounting Medium with DAPI (Vector Laboratories, Inc.), and images were captured using an EVOS Digital Inverted Microscope (AMG Life Technologies).

Transwell migration/invasion assays. Transwell migration and invasion assays were performed in $6.5-\mathrm{mm}$ inserts with an $8-\mu \mathrm{m}$ pore size (Corning, Inc.). For the invasion assays, the membranes were coated with $50 \mu 1$ of MyoGel $(2.4 \mathrm{mg} / \mathrm{ml})(31,32)$ solidified with type I collagen from rat tail $(0.8 \mathrm{mg} / \mathrm{ml}$, Corning, Inc.). Cells (70,000 cells/well) were plated into the upper chamber in $200 \mu \mathrm{l}$ of serum-free media (OTSCCs) or supplement-free media (IHGK) with $0.5 \%$ lactalbumin (Sigma Aldrich; Merck KGaA) and the indicated amounts of EGF (positive control) or LL-37. As a chemoattractant, $500 \mu \mathrm{l}$ of media supplemented with $10 \%$ FBS (OTSCCs) or supplements (IHGK) was used in the lower chamber. Experiment times varied between $24 \mathrm{~h}$ for migration assays and 2-6 days for invasion assays. The cells were fixed in $4 \%$ neutral-buffered formalin and stained with $1 \%$ toluidine blue in $1 \%$ borax solution. The dye excess was washed out and the non-invading cells were gently removed from the upper part of the membrane with a cotton swab. The stained cells were then eluted in $1 \%$ SDS solution and absorbance was measured at $650 \mathrm{~nm}$ using the Victor2 Microplate Reader (Perkin Elmer Wallac). Results represent the average of three independent experiments, performed in triplicate.

Immunoblotting. For analysis of the hCAP18/LL-37 amount, cells were cultured for $72 \mathrm{~h}$ in normal culture medium. For signal transduction analysis, cells were starved for $24 \mathrm{~h}$ and then stimulated with the indicated amounts of compounds for $1 \mathrm{~h}$. For EMT analysis, cells were cultured with compounds for $48 \mathrm{~h}$ in normal culture medium. Cells were lysed with elution buffer [50 mM Tris- $\mathrm{HCl} \mathrm{pH} 7.5,10 \mathrm{mM} \mathrm{CaCl}_{2}, 150 \mathrm{mM} \mathrm{NaCl}$, $0.05 \%$ (v/v) Brij-35 (Sigma Aldrich; Merck KGaA)] including Complete EDTA-free protease inhibitor cocktail (Roche). For signal transduction analysis, also a PhosSTOP ${ }^{\mathrm{TM}}$ phosphatase inhibitor (Roche) was added. The cell debris was removed by centrifugation and protein concentrations were measured with a DC Protein assay (Bio-Rad). For analysis of hCAP18/LL-37, $50 \mu \mathrm{g}$ of soluble protein, and for signal transduction and EMT analysis $30 \mu \mathrm{g}$ of soluble protein were separated under reducing conditions on a 15 and 10\% SDS-PAGE gel, respectively. The proteins were transferred to an Immobilon-P membrane (Millipore), which was blocked with $5 \%$ milk powder (Bio-Rad) or for the phosphorylated antibodies with 
5\% BSA (Roche) in Tris-buffered saline and 0.1\% Tween 20. Membranes were incubated overnight with hCAP18/LL-37 (dilution 1:500, HM2070, Hycult Biotech), EGF receptor (dilution 1:1,000, 4267), phospho-EGF receptor (dilution 1:1,000, Tyr1068, 3777), p44/42 MAPK (dilution 1:1,000, Erk1/2, 9102), phospho-p44/42 MAPK (dilution 1:2,000, Erk1/2, Thr202/Tyr204, 9106), Akt (dilution 1:1,000, 9272), phospho-Akt (dilution 1:1,000, Ser473, 9271) antibodies (all from Cell Signaling Technology, Inc.), E-cadherin antibody (dilution 1:1,000, 4065, Cell Signaling Technology), mouse anti-vimentin (dilution 1:750, M0725, Dako) or anti- $\beta$-actin (dilution 1:2,000, ab8226, Abcam), followed by a biotinylated anti-rabbit IgG (dilution 1:5,000, cat. no. E035301-2; Dako) or anti-mouse IgG (dilution 1:5,000; cat. no. E035401-2; Dako) and Vectastain ABC kit (Vector Laboratories). Immunocomplexes were visualized using a Pierce ECL Western blotting substrate (Thermo Fisher Scientific, Inc.) and the Luminescent image analyser LAS-3000 (Fujifilm). Quantification of protein levels was performed with Fiji software 1.51w (33) and $\beta$-actin was used to normalize the results. The results represent the average of two to four independent experiments in triplicate, separated two to three times on SDS-PAGE gels.

Immunofluorescence staining. The HSC-3 cells were seeded in normal media on an 8 -well Lab-Tek ${ }^{\circledR}$ Chamber Slide $^{\mathrm{TM}}$ System (Nunc) at a density of 12,500 cells/well in duplicate. After a $24 \mathrm{~h}$ culture, cells were starved for $24 \mathrm{~h}$ and then stimulated with $100 \mathrm{ng} / \mathrm{ml}$ EGF (positive control) (ProSpec) and $50 \mu \mathrm{g} / \mathrm{ml}$ LL-37 (Isca Biochemicals) in serum-free media for $1 \mathrm{~h}$. Cells were washed two times with PBS and fixed with $4 \%$ neutral-buffered formalin for $30 \mathrm{~min}$ and washed three times with PBS. After permeabilization in $0.1 \%$ TritonX-100 in PBS, the samples were blocked in $1 \%$ BSA, PBS- $0.1 \%$ Tween 20 (PBS-T) for $1 \mathrm{~h}$ at room temperature (RT). The cells were incubated with EGF receptor antibody (dilution 1:50; cat. no. 4267; Cell Signaling Technology, Inc.) overnight at $4^{\circ} \mathrm{C}$, followed by incubation with Alexa Fluor 594 anti-rabbit secondary antibody (Invitrogen; Thermo Fisher Scientific, Inc.) in $1 \%$ BSA/PBS-T in a humidified chamber for $1 \mathrm{~h}$ at RT. Cell nuclei were stained with DAPI (Thermo Fisher Scientific, Inc.), followed by rinsing three times with PBS. Cells were embedded with Immu-Mount (Thermo Fisher Scientific, Inc.) and examined using a Zeiss LSM 510 Meta confocal microscope with LSM software (Zeiss).

Zymography. Approximately 400,000 cells/well on a 6-well plate were treated with the indicated amounts of compounds in OptiMEM (Gibco; Thermo Fisher Scientific, Inc.) for $24 \mathrm{~h}$. Seventy-five microliters of conditioned medium was concentrated with a speed-vac device and samples were analyzed with gelatin zymography in $10 \%$ SDS-PAGE, casted in the presence of $1 \mathrm{mg} / \mathrm{ml}$ fluorescently labelled gelatin [2-methoxy-2,4diphenyl-3-(2H) furanone (Fluka)]. After electrophoresis, SDS was removed by $2.5 \%$ Triton X-100 to renature the gelatinases, and gels were incubated in $50 \mathrm{mM}$ Tris- $\mathrm{HCl}$ buffer, $\mathrm{pH} \mathrm{7.8,}$ $150 \mathrm{mM} \mathrm{NaCl}, 5 \mathrm{mM} \mathrm{CaCl}, 1 \mu \mathrm{M} \mathrm{ZnCl}_{2}$ overnight at $37^{\circ} \mathrm{C}$. The degradation of fluorescent gelatin was visualized using Molecular imager ChemiDoc XRS+ (Bio-Rad) (34). The intensities of bands were quantified with Fiji software (33). The results represent the average of two separate sample sets in triplicate, each analyzed three times. The band intensities were normalized to the cellular soluble protein concentration.

Patients and sample collection. This retrospective study was approved by the Ethics Committee of the Northern Ostrobothnia Hospital District, Finland (49/2010, 56/2010, 46/2013) and the Finnish National Supervisory Authority for Welfare and Health (6865/05.01.00.06/2010, 7449/06.01.03.01/2013). OTSCC tissue specimens were obtained from 75 patients diagnosed and treated at the Oulu University Hospital, Finland, between 1990 and 2016. Clinical and pathological information were collected from a retrospective review of patient medical records, and tumor histological grade was defined in accordance with the World Health Organization classification (Table I). Samples of normal tongue tissue and tongue dysplasia were obtained from 26 patients diagnosed and treated at the Oulu University Hospital, Finland, and were histopathologically graded as normal $/$ mild $(n=9)$ or moderate/severe $(n=16)$ (Table II).

Immunohistochemistry. Patient samples were fixed with $10 \%$ neutral buffered formalin, embedded in paraffin, and serially sectioned at $4 \mu \mathrm{m}$. Immunohistochemistry for hCAP18/LL-37 was performed using REAL EnVision detection system, peroxidase/DAB+, Rabbit/Mouse kit from Dako as described elsewhere (35). Briefly, the sections were deparaffinized in xylene and rehydrated with graded ethanol solutions. Following peroxidase blocking with peroxidase blocking solution (Dako) for $10 \mathrm{~min}$, the sections were incubated with primary, monoclonal antibody to human LL-37/hCAP18 clone 3D11 (dilution 1:300; cat. no. HM2070; Hycult Biotech) for $30 \mathrm{~min}$ at RT, followed by incubation with streptavidin-biotinylated horseradish peroxidase (StreptABComplex/HRP; cat. no. K5007; Dako) for $30 \mathrm{~min}$. The reactions were developed with diaminobenzydine (DAB), and the sections were then counterstained with Mayer's haematoxylin (Reagena). An isotype-specific immunoglobulin mouse IgG1 (dilution 1:300; cat. no. X0931; Dako) was used as a negative control. LL-37/hCAP18 antibody-stained immune cells in tumor stroma were assessed similarly as shown previously (14). This was considered as a positive control of LL-37/hCAP18 staining.

Semi-quantitative assessment. All samples were examined by three independent observers (MR, MV and PCR) blinded to the patient clinical information. Discrepancies in the scoring were settled by an experienced oral pathologist (TS). In OTSCC, immunopositivity for hCAP18/LL-37 was evaluated according to overall staining intensity and area (percentage of positively stained tissues) from the whole sample with x10 magnification and the most representative fields were selected and cells counted using x20 magnification. The existence of yellow/brown-stained cells was defined as expression of hCAP18/LL-37. If the staining intensity was heterogeneous, then scoring was based on the greatest degree of intensity. An immunoreactive score (IRS) was used for the hCAP18/LL-37 scoring. The IRS was obtained by multiplying the intensity score ( 0 , no staining; 1 , weak staining; 2 , moderate staining; 3 , strong staining) by the area score $(1, \leq 25 \% ; 2,>25$ to $\leq 50 \%$ and $3,>50 \%$ of cancer cells), yielding an IRS range from 0 to 9 . An IRS score $\leq 1$ was considered as negative hCAP18/LL-37 expression, while $\geq 2$ was classified 
Table I. Clinicopathological features of the patients with OTSCC $(\mathrm{N}=75)$.

\begin{tabular}{|c|c|}
\hline Characteristics & Data $n(\%)$ \\
\hline \multicolumn{2}{|l|}{ Sex } \\
\hline Male & $44(59)$ \\
\hline Female & $31(41)$ \\
\hline \multicolumn{2}{|l|}{ Age at diagnosis (years) } \\
\hline$\leq 65$ & $34(45)$ \\
\hline$>65$ & $41(55)$ \\
\hline Range & $26-88$ \\
\hline Mean & 65 \\
\hline \multicolumn{2}{|l|}{ Follow-up } \\
\hline Time & Months \\
\hline Range & $2-251$ \\
\hline Mean & 40 \\
\hline \multicolumn{2}{|l|}{ Cause of death } \\
\hline Alive & $41(55)$ \\
\hline Cancer & $19(25)$ \\
\hline Other & $12(15)$ \\
\hline No information & $4(5)$ \\
\hline \multicolumn{2}{|l|}{ Clinical stage } \\
\hline I-II & $39(52)$ \\
\hline III-IV & $36(48)$ \\
\hline \multicolumn{2}{|l|}{ Histopathological grade } \\
\hline 1 & $14(19)$ \\
\hline 2 & $41(55)$ \\
\hline 3 & $16(21)$ \\
\hline No information & $4(5)$ \\
\hline \multicolumn{2}{|l|}{ Lymph node status } \\
\hline pNO & 37 (49) \\
\hline $\mathrm{pN}+$ & $25(33)$ \\
\hline No information & $13(55)$ \\
\hline \multicolumn{2}{|l|}{ Neck dissection } \\
\hline Yes & $55(73)$ \\
\hline No & $19(25)$ \\
\hline No information & $1(1)$ \\
\hline \multicolumn{2}{|l|}{ Adjuvant treatment } \\
\hline No & $37(49)$ \\
\hline Radiotherapy & $25(33)$ \\
\hline Radio + chemotherapy & $12(16)$ \\
\hline \multicolumn{2}{|l|}{ Recurrence } \\
\hline Yes & $21(28)$ \\
\hline No & $50(67)$ \\
\hline No information & $4(5)$ \\
\hline \multicolumn{2}{|c|}{ hCAP18/LL-37 immunostaining } \\
\hline Negative & $40(53)$ \\
\hline Positive & $35(47)$ \\
\hline
\end{tabular}

OTSCC, oral tongue squamous cell carcinoma.

as positive hCAP18/LL-37 immunoexpression. For statistical analysis, the OTSCC patients were classified into two groups,
Table II. Clinicopathological features of the patients with dysplasia $(\mathrm{N}=26)$.

\begin{tabular}{lc}
\hline Characteristics & Data n (\%) \\
\hline Sex & \\
Male & $14(54)$ \\
Female & $12(46)$ \\
Age (years) & \\
$\leq 60$ & $11(42)$ \\
$>60$ & $15(52)$ \\
Range & $27-92$ \\
Mean & 60 \\
hCAP18/LL-37 immunostaining & \\
Normal/mild dysplasia & $1(11)$ \\
Negative & $8(89)$ \\
Positive & \\
Moderate/severe dysplasia & $9(53)$ \\
Negative & $8(47)$ \\
Positive & \\
\hline hCAP18, human cationic antimicrobial protein 18. & \\
\hline
\end{tabular}

'low expression' included those with negative or weak expression (IRS score $\leq 1$ ) and 'high expression' included those with moderate or strong expression (IRS score $\geq 2$ ). The outcomes were categorized as overall survival: Time from treatment initiation until death or last known date alive; disease-specific survival: Time from treatment initiation until death due to cancer or last known date alive and disease-free survival: Time from treatment initiation until diagnosis of the first recurrence (local, regional or distant) or last follow-up information for those without recurrence. Normal and dysplastic samples were evaluated by intensity of staining on epithelial layers ( 0 , no staining; 1 , weak staining; 2, moderate staining; 3 , strong staining). A score $\leq 1$ was considered as negative hCAP18/LL-37 expression, while $\geq 2$ was classified as positive for hCAP18/LL-37. For statistical analysis, samples were grouped as 'normal tongue tissue or mild dysplasia' and 'moderate or severe dysplasia'. By creating these two broad groups, we aimed to reduce the subjectivity inherent to grading dysplasia.

Statistical analysis. Calculations were performed with IBM SPSS Statistics 26 (IBM Corp.). In all in vitro cell experiments, P-values were calculated with the independent-samples Kruskal-Wallis test and significance was adjusted by the Bonferroni correction for multiple tests. In in vitro experiments the results are presented as average \pm standard deviation (SD). For finding correlations between the hCAP18/LL-37 staining in immunohistochemistry samples and patient clinicopathological parameters, the Spearman's rank correlation coefficient was used. Furthermore, a Kaplan-Meier test was used to construct the survival curves. To determine the significance of expression of hCAP18/LL-37 in OTSCC and normal/tongue dysplasia tissues, the Kruskal-Wallis test with Dunn's post hoc test was used. P-value $<0.05$ was considered indicative of a statistically significant result. 

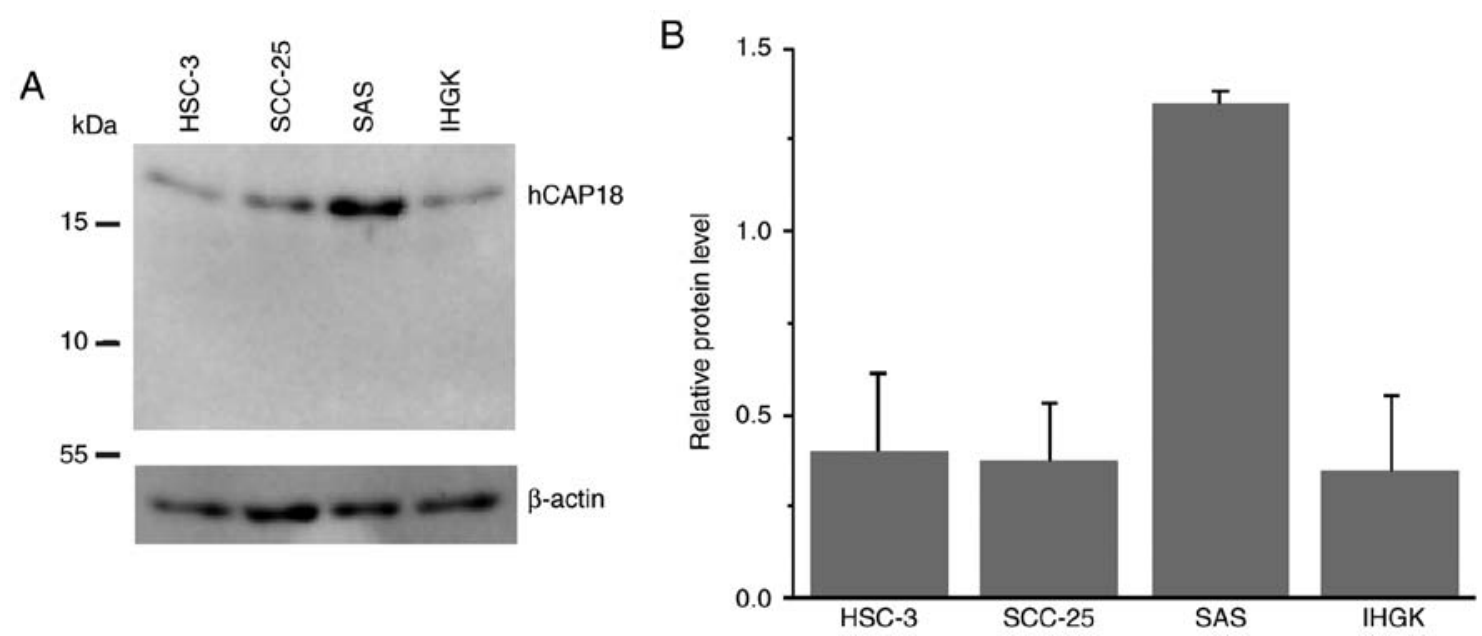

Figure 1. Endogenous protein level of LL-37/hCAP18 in OTSCC cell lines and IHGK cells. HSC-3, SCC-25, SAS and IHGK cell lysates (50 $\mu \mathrm{g}$ protein) were separated on SDS-PAGE gels. The amount of hCAP18/LL-37 was analysed with (A) immunoblotting and (B) $\beta$-actin was used as a control to normalize the quantities. A shows a representative immunoblot. The quantification of protein levels was conducted from four independent experiments with Fiji software. OTSCC, oral tongue squamous cell carcinoma; hCAP18/LL-37, human host defense cationic antimicrobial peptide-18/antimicrobial peptide leucine-leucine-37.

\section{Results}

Human cationic antimicrobial protein-18 (hCAP18) is expressed in OTSCC cells and exogenous LL-37 has a fluctuating effect on the cells. The human cationic antimicrobial protein-18/antimicrobial peptide LL-37 (hCAP18/LL-37) has been found in varying degrees at the mRNA and protein levels in several cancer cell lines (14-16). We first evaluated the hCAP18/LL-37 expression in human OTSCC cell lines HSC-3, SCC-25 and SAS, and in dysplastic papillomavirus HPV16 immortalized human oral epithelial (IHGK) cells by immunoblotting (Fig. 1). Our analysis revealed that only hCAP18 $(19 \mathrm{kDa})$ was present in all cells, while the LL-37 peptide (5 kDa) was absent (Fig. 1A). The immunoblot results showed that the OTSCC cell line SAS contained the highest amount of hCAP18 among the cell lines tested (Fig. 1A and B). Our analysis disclosed that OTSCC cells express hCAP18, which may be further cleaved to LL-37 in the extracellular space.

LL-37 has been shown to affect cell proliferation of several cancer cell lines (13-16,23,36-43). Thus, we assessed the effect of the recombinant LL-37 on proliferation of HSC-3, SCC-25, SAS and IHGK cell lines (Fig. 2). Cells were treated with increasing doses of synthetic LL-37 peptide in the presence of serum since the effects of the peptide appear to be dependent on serum $(14,43)$. Epidermal growth factor (EGF) was used as a positive control (44). After 24 and $48 \mathrm{~h}$, the highest dose $(50 \mu \mathrm{g} / \mathrm{ml})$ of LL-37 reduced the proliferation of OTSCC and dysplastic IHGK cell lines compared with the corresponding untreated controls (Fig. 2A and B). Doses of $0.5-10 \mu \mathrm{g} / \mathrm{ml}$ had reducing effects on SCC-25 cells at $24 \mathrm{~h}$ and on SAS and IHKG cells at $48 \mathrm{~h}$, otherwise these doses had no marked impact on proliferation. The addition of $100 \mathrm{ng} / \mathrm{ml}$ EGF, however, reduced the proliferation of all cell lines at 24 and $48 \mathrm{~h}$. Interestingly, after $72 \mathrm{~h}$ the effects of LL-37 and EGF were somewhat reversed. Especially in SAS cells the longer incubation time with all doses of LL-37 induced cell proliferation and in HSC-3 cells with a dose of $50 \mu \mathrm{g} / \mathrm{ml}$. Also at this time point, no marked effect was observed on the other cell lines.
To further assess possible apoptotic cell death effects of LL-37 and to validate the BrdU proliferation assay results, we performed a TUNEL assay for HSC-3 control, $100 \mathrm{ng} / \mathrm{ml}$ EGF and $50 \mu \mathrm{g} / \mathrm{ml}$ LL-37-treated cells (Fig. S1). After $48 \mathrm{~h}$ a notable amount of stained cells with DNA fragmentation was noted only in the LL-37-treated cells, indicating that reduction in proliferation was probably caused by apoptosis. Our data suggest that LL-37, especially at high doses, mostly reduces proliferation of OTSCC cells, but its effects may fluctuate depending on incubation time and cell line.

\section{LL-37 stimulates the migration and invasion of OTSCC cell} lines. It has been reported that LL-37 promotes migration and invasion of several cancer cell lines $(14,16,36-38,43)$. We assayed the effect of LL-37 on OTSCC cell line migration using Transwell inserts (Fig. 3A). To elucidate the effects on invasion, we used Transwells coated with Myogel (31) and type I collagen mixture (Fig. 3B). The OTSCC cell lines tested display different aggressiveness and invasive ability (45-49). Because dysplastic IHGK cells did not invade, their migration was only assayed (Fig. 3A). All of the cancer cell lines showed a slightly increased migration and invasion when treated with $0.5 \mu \mathrm{g} / \mathrm{ml}$ LL-37 (Fig. 3A and B). For IHGK cells, the addition of $0.5 \mu \mathrm{g} / \mathrm{ml}$ LL-37 only marginally increased their migration. In SAS cells, $50 \mu \mathrm{g} / \mathrm{ml}$ LL-37 clearly increased the invasion but not migration, whereas in the other cell lines this dose led to decreased invasion or migration compared with the controls. The treatment with our positive control $100 \mathrm{ng} / \mathrm{ml}$ EGF increased the migration and invasion of all three OTSCC cell lines compared with the control. On the other hand, the migration of IHGK cells decreased with the addition of $100 \mathrm{ng} / \mathrm{ml}$ EGF. Our data suggest that LL-37 induces migration and invasion of OTSCC cells, but the effect depends on the cell line.

\section{LL-37 affects the amount of EGFR on the plasma membrane.} In normal epithelial and lung cancer cells, LL-37 appears to mediate its actions on cell proliferation and migration mostly via EGFR by the activation of downstream 


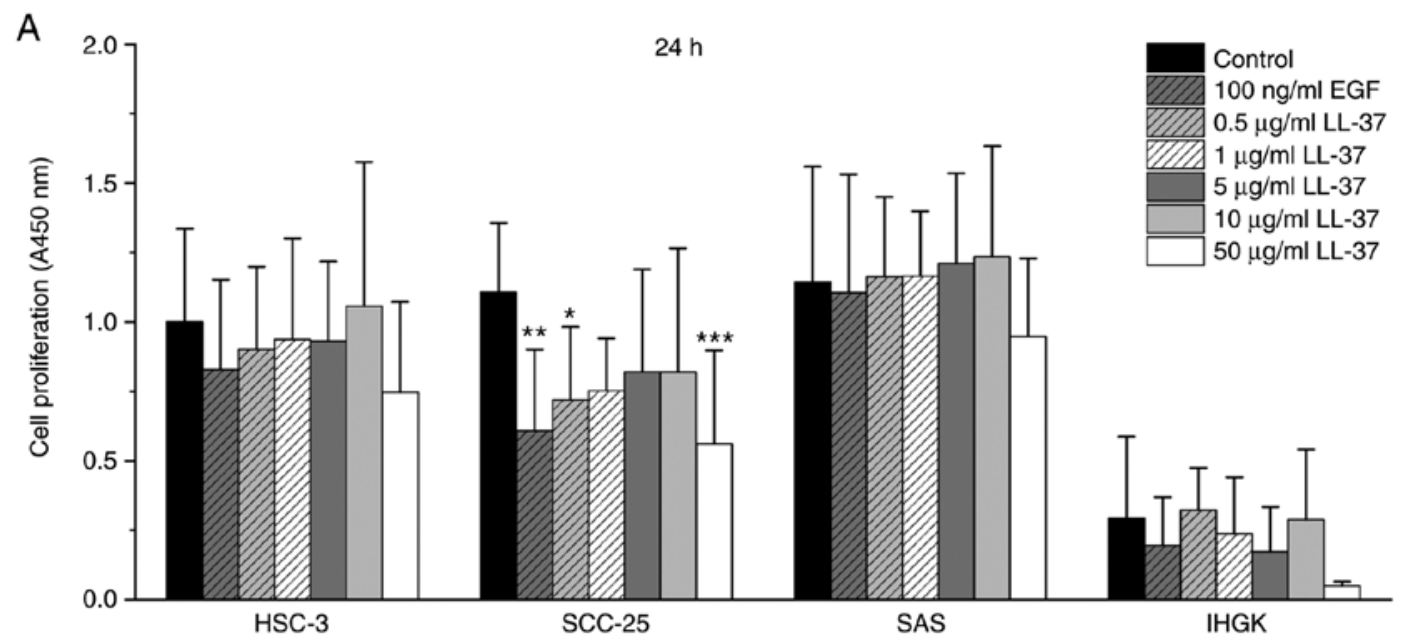

B

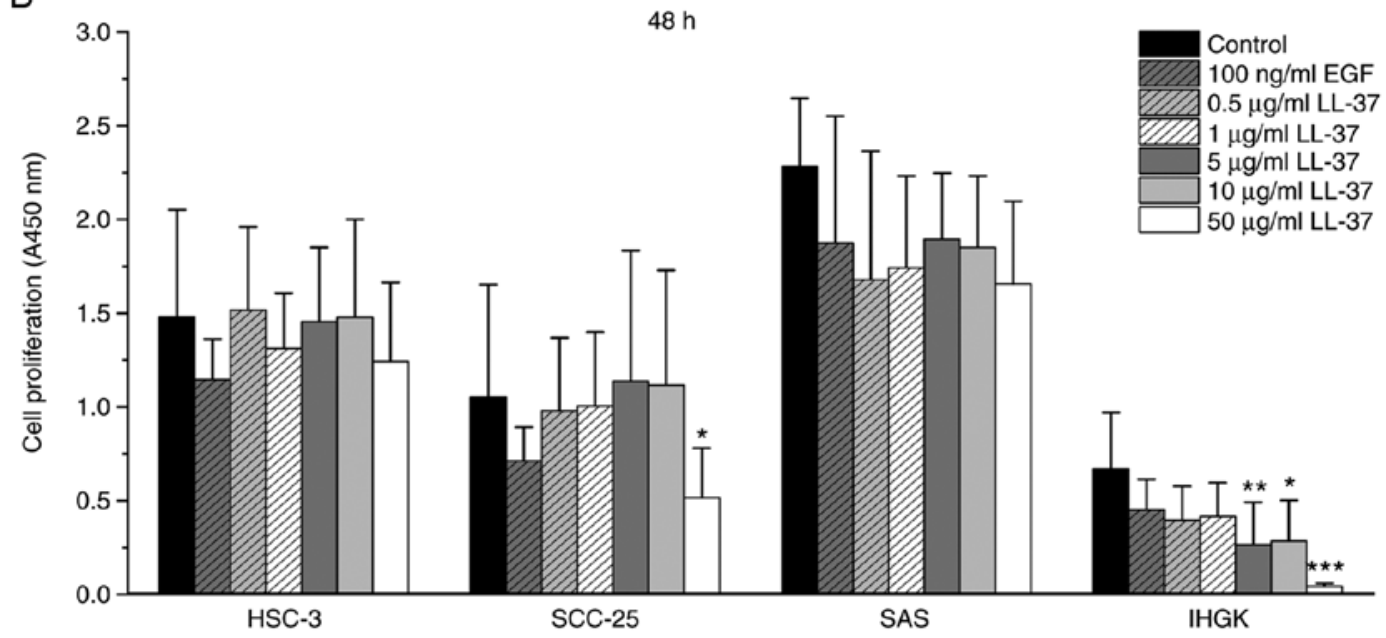

C

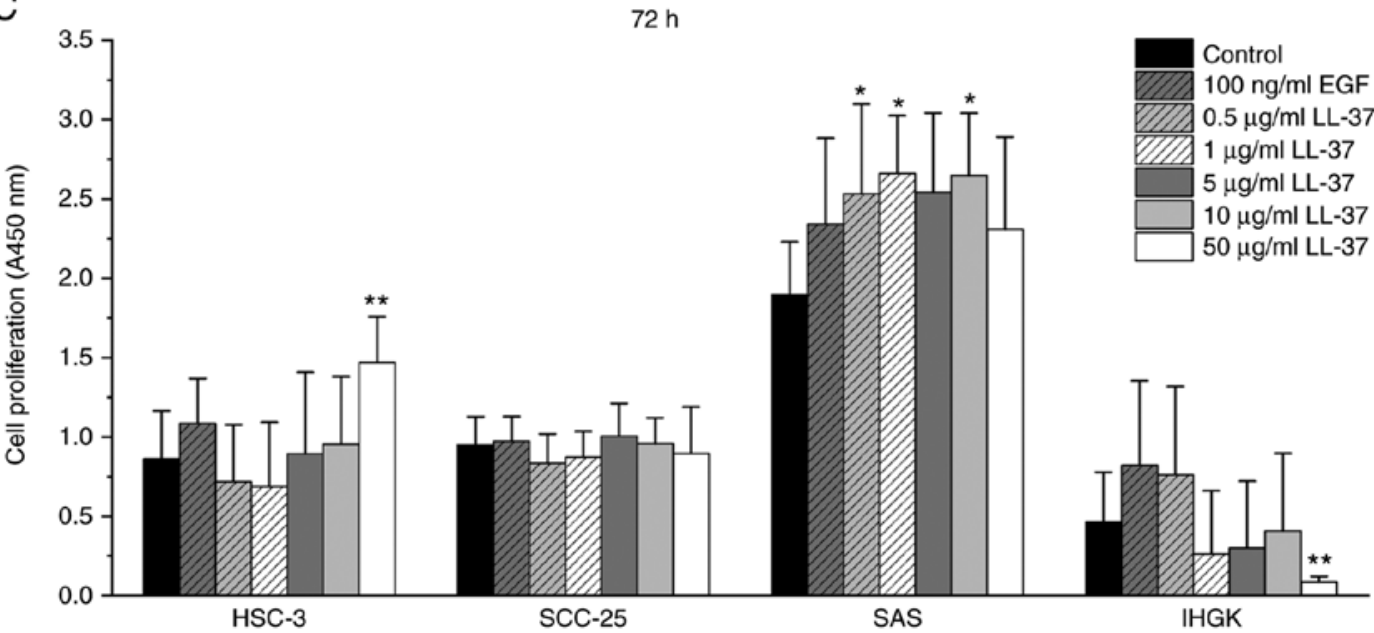

Figure 2. Proliferation of EGF- or LL-37-treated OTSCC cell lines and IHGK cells. HSC-3, SCC-25, SAS and IHGK cells were treated with the indicated doses of EGF or LL-37 peptide. Proliferation was measured after (A) 24, (B) 48 and (C) $72 \mathrm{~h}$ using Cell Proliferation ELISA BrdU. The values represent the average \pm SD of four separate experiments. P-values were calculated with the independent-samples Kruskal-Wallis test and significance was adjusted by the Bonferroni correction for multiple tests. ${ }^{*} \mathrm{P}<0.05,{ }^{* *} \mathrm{P}<0.01,{ }^{* * * *} \mathrm{P}<0.001$ compared with the control. EGF, epidermal growth factor; OTSCC, oral tongue squamous cell carcinoma; LL-37, antimicrobial peptide leucine-leucine-37.

pathways $(15,26,27,43,50)$. Since EGFR appears to have a prognostic value in oral cancer (51) and results demonstrate that LL-37 treatment affects cell proliferation, migration and invasion, we tested phosphorylation of EGFR, extracellular signal-regulated protein kinases 1 and $2($ Erk1/2) and the serine/threonine kinase Akt by immunoblotting (Fig. 4).
Phosphorylated EGFR was only detected in the HSC-3 and SCC- 25 cells, not in the SAS or IHGK cells. Phosphorylation of EGFR in HSC-3 cells increased only when our positive control $100 \mathrm{ng} / \mathrm{ml}$ EGF was added, but in SCC-25 cells it also slightly increased with the addition of $50 \mu \mathrm{g} / \mathrm{ml} \mathrm{LL}-37$. The most evident finding was that the amount of total EGFR 


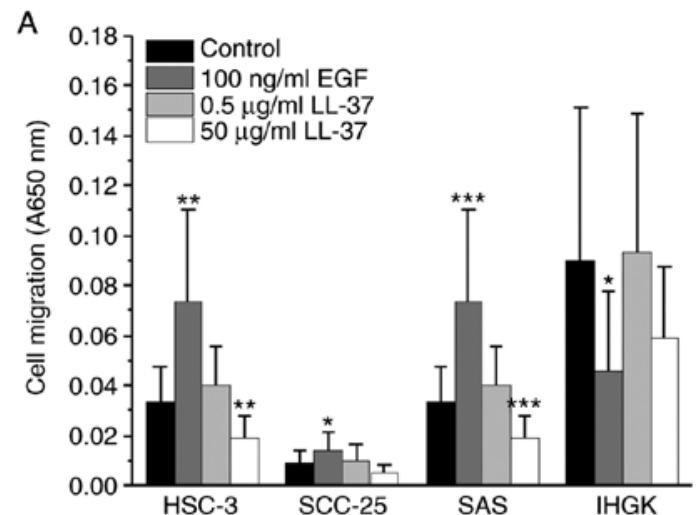

B

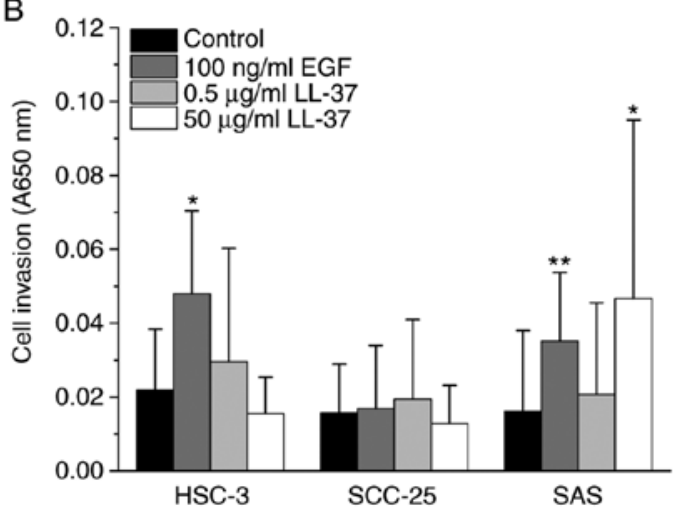

Figure 3. Transwell migration and invasion of EGF- or LL-37-treated OTSCC cell lines and migration of IHGK cells. (A) HSC-3, SCC-25, SAS and IHGK cell migration in Transwell inserts and (B) OTSCC cell line invasion in Myogel-coated Transwells after treatment with the indicated doses of EGF or LL-37 peptide. The migrated/invaded cells were stained with Toluidine Blue, the stain was dissolved in $1 \%$ SDS solution and the absorbance at $650 \mathrm{~nm}$ was measured. The values represent the average \pm SD of three separate experiments. P-values were calculated with the independent-samples Kruskal-Wallis test and significance was adjusted by the Bonferroni correction for multiple tests. ${ }^{*} \mathrm{P}<0.05,{ }^{* *} \mathrm{P}<0.01,{ }^{* * *} \mathrm{P}<0.001$ compared with the control. EGF, epidermal growth factor; OTSCC, oral tongue squamous cell carcinoma; LL-37, antimicrobial peptide leucine-leucine-37.

markedly increased in all cell lines when cells were stimulated with $50 \mu \mathrm{g} / \mathrm{ml} \mathrm{LL}-37$. To further study the localization of EGFR in HSC-3 cells, we used immunocytochemistry (Fig. S2). Our staining showed that in starved control cells EGFR localized both to the plasma membrane and to the cytosol close to the nucleus. In EGF-stimulated cells, the brightest staining was observed as droplets close to the nucleus. In LL-37-treated cells, the strong EGFR staining lined the plasma membrane of HSC -3 cells. These data suggest that a high concentration of LL-37 affects the stability of the EGFR protein rather than its expression and phosphorylation.

An increased phosphorylation of Erk1/2 compared with the starved control was observed in all cancer cell lines when positive control $100 \mathrm{ng} / \mathrm{ml}$ EGF was added, but not in dysplastic IHGK cells (Fig. 4). The addition of $0.5 \mu \mathrm{g} / \mathrm{ml} \mathrm{LL}-37$ led to a marked increase in the phosphorylation of Erk1/2 in SCC-25 cells, but in the other cell lines it had a slightly decreasing effect or no effect at all. Addition of $50 \mu \mathrm{g} / \mathrm{ml}$ LL-37 decreased the phosphorylation of Erk1/2 in all cell lines, and it was statistically significant in SAS cells. No significant changes were seen in the total amount of Erk1/2 with any of the treatments. The phosphorylation of Akt increased with positive control
$100 \mathrm{ng} / \mathrm{ml} \mathrm{EGF}$ only in HSC-3 and SAS cells. In HSC-3 and SCC-25 cells, there was a dose-dependent decrease in Akt phosphorylation with LL-37 stimulation. Interestingly, in SAS and IHKG cells the addition of $50 \mu \mathrm{g} / \mathrm{ml} \mathrm{LL}-37$ increased the Akt phosphorylation, even though $0.5 \mu \mathrm{g} / \mathrm{ml}$ LL-37 slightly reduced the Akt phosphorylation. For the total protein amount of Akt, the treatments seemed not to have a significant effect. Our data suggest that OTSCC and IHKG cell lines respond differently to the EGF and LL-37 treatments with regard to the downstream pathways.

LL-37 induces secretion of matrix metalloproteinase (MMP)2 and MMP9. LL-37 has been shown to affect epithelial-to-mesenchymal transition (EMT) $(18,52)$ and to induce the amount of matrix metalloproteinases (MMPs) $(14,17,53)$. Our invasion assay results suggest that LL-37 also induces EMT or activates expression of MMPs in our cell lines. We therefore analyzed common epithelial marker E-cadherin and mesenchymal marker vimentin by immunoblotting and used zymography to evaluate the amounts of pro- and active forms of MMP2 and MMP9. Additionally, EGF is known to induce EMT and also MMP expression in cancer cell lines (54). LL-37 treatments only slightly reduced or induced the amount of E-cadherin in the different cell lines (Fig. S3A-H). EGF reduced E-cadherin levels in all cell lines, significantly in SCC-25 cells (Fig. S3C and D). Treatment with $0.5 \mu \mathrm{g} / \mathrm{ml}$ LL-37 reduced or had no effect on the level of vimentin, while $50 \mu \mathrm{g} / \mathrm{ml}$ LL-37 induced vimentin in HSC-3 and SCC-25 cells. EGF markedly induced vimentin level only in SCC-25 cells (Fig. S3C and D), while in other cell lines it somewhat reduced the vimentin level.

On zymogram gels, we found bands corresponding to pro-MMP9 and pro- and active MMP2 in the HSC-3 and SCC-25 cells (Fig. S4A and C), but in SAS and IHGK cells (Fig. S4E and G) only pro-forms of MMP2 and MMP9 were detected. Quantification of the bands showed that $50 \mu \mathrm{g} / \mathrm{ml}$ LL-37 increased the amount of these MMPs in the HSC-3, SAS and IHGK cells (Fig. S4B, F and H), but in SCC-25 cells it slightly decreased the MMPs (Fig. S4D). In addition, $0.5 \mu \mathrm{g} / \mathrm{ml}$ LL-37 mostly induced the amount of MMPs. Furthermore, $100 \mathrm{ng} / \mathrm{ml}$ EGF increased the amount of pro-MMP9 in the HSC-3, SAS and IHGK cells. For pro-MMP2, EGF had a slightly reducing effect or no effect in all cell lines. However, the level of active MMP2 slightly increased in the HSC-3 and SCC-25 cells. Our results suggest that LL-37 may induce the amount of MMP2 and MMP 9, however, LL-37 did not induce marked EMT in the tested cell lines.

hCAP18/LL-37 is expressed in OTSCC tissues and tongue dysplasia but is not associated with clinicopathological characteristics and/or outcome of the patients. The tissue expression of hCAP18/LL-37 has been analyzed in several cancer types $(13-19,21,40,41)$. Our immunohistochemistry results showed positive immunostaining for hCAP18/LL-37 in 35/75 OTSCC samples (47\%) (Table I). In positive samples, both peripheral and central cells of neoplastic islands were stained (Fig. 5A). In oral tongue samples, 8/9 normal $/ \mathrm{mild}$ $(89 \%)$ and 8/17 moderate/severe oral dysplasia (47\%) showed positivity for hCAP18/LL-37 (Table II), and positive staining was detected within the epithelial layers of tissue (Fig. 5B). 

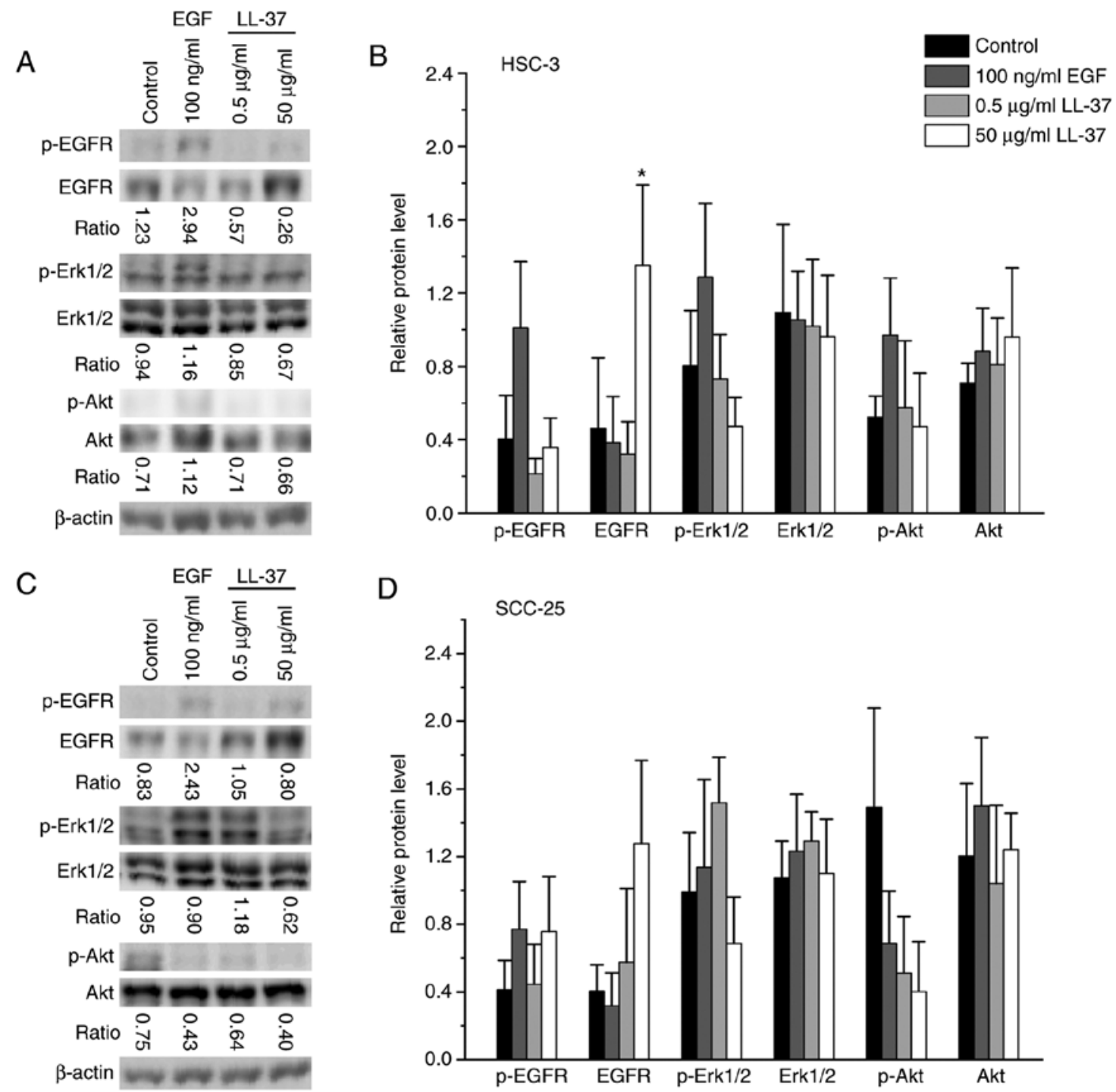

Figure 4. Immunoblot analysis of EGFR, Erk1/2 and Akt activation in EGF- or LL-37-treated OTSCC cell lines and IHGK cells. Cells were starved for $24 \mathrm{~h}$ and stimulated with the indicated doses of EGF or LL-37 for $1 \mathrm{~h}$. Starved non-stimulated cells were used as a control. Cell homogenates ( $30 \mu \mathrm{g}$ of soluble protein) were separated on SDS-PAGE gels. The amounts of EGFR, Erk1/2 and Akt and their phosphorylated forms were analyzed with immunoblots in (A) HSC-3 and (C) SCC-25 cells. In A and C, representative immunoblots are shown. The average ratio between the optical density of phosphorylated protein/total protein was calculated. $\beta$-actin was used as a control to normalize the quantities of proteins in (B) HSC-3 and (D) SCC-25 cells using Fiji software. The results represent average \pm SD of two independent experiments, separated three times on SDS-PAGE gels. P-values were calculated with the independent-samples Kruskal-Wallis test and significance was adjusted by the Bonferroni correction for multiple tests. ${ }^{*} \mathrm{P}<0.05$, compared with the control.

The inter-observer k-value, representing the degree of agreement among readers, was 0.88 for OTSCC samples and 0.95 for normal and tongue dysplasia samples. The hCAP18/LL-37 levels were higher in normal/mild dysplasia samples than in OTSCC samples $(\mathrm{P}<0.05)$. In addition, the hCAP18/LL-37 expression was higher in normal/mild dysplasia than in moderate/severe dysplasia, albeit not significantly ( $\mathrm{P}=0.059$, Fig. 5C). However, no differences between OTSCC and moderate/severe dysplasia were observed $(\mathrm{P}>0.05)$. To determine the correlation between levels of hCAP18/LL-37 and various clinicopathological features, patients of the OTSCC cohort were divided into low and high expression subgroups. As shown in Table III, the expression of hCAP18/LL-37 in OTSCC tissues was not correlated with the clinicopathological characteristics of the cancer patients. We next investigated the association between expression of hCAP18/LL-37 and clinical prognosis of OTSCC patients.
hCAP18/LL-37 survival analyses based on univariate log-rank test revealed no significant association with overall survival (Fig. S5A), disease-specific survival (Fig. S5B) or disease-free survival (Fig. S5C). Taken together, our results suggest that hCAP18/LL-37 shows a lower expression in OTSCC tissues than in normal/mild dysplasia samples, but its amount is not correlated with clinicopathological features and/or outcome of patients with OTSCC.

\section{Discussion}

Human host defense cationic antimicrobial peptide-18/antimicrobial peptide LL-37 (hCAP18/LL-37) has been detected in healthy human tongue (28) and oral squamous cell carcinoma (OSCC) (21), but its role remains unclear. Recently a study reported that low expression of hCAP18/LL-37 in poorly differentiated OSCC was related to lymph node 

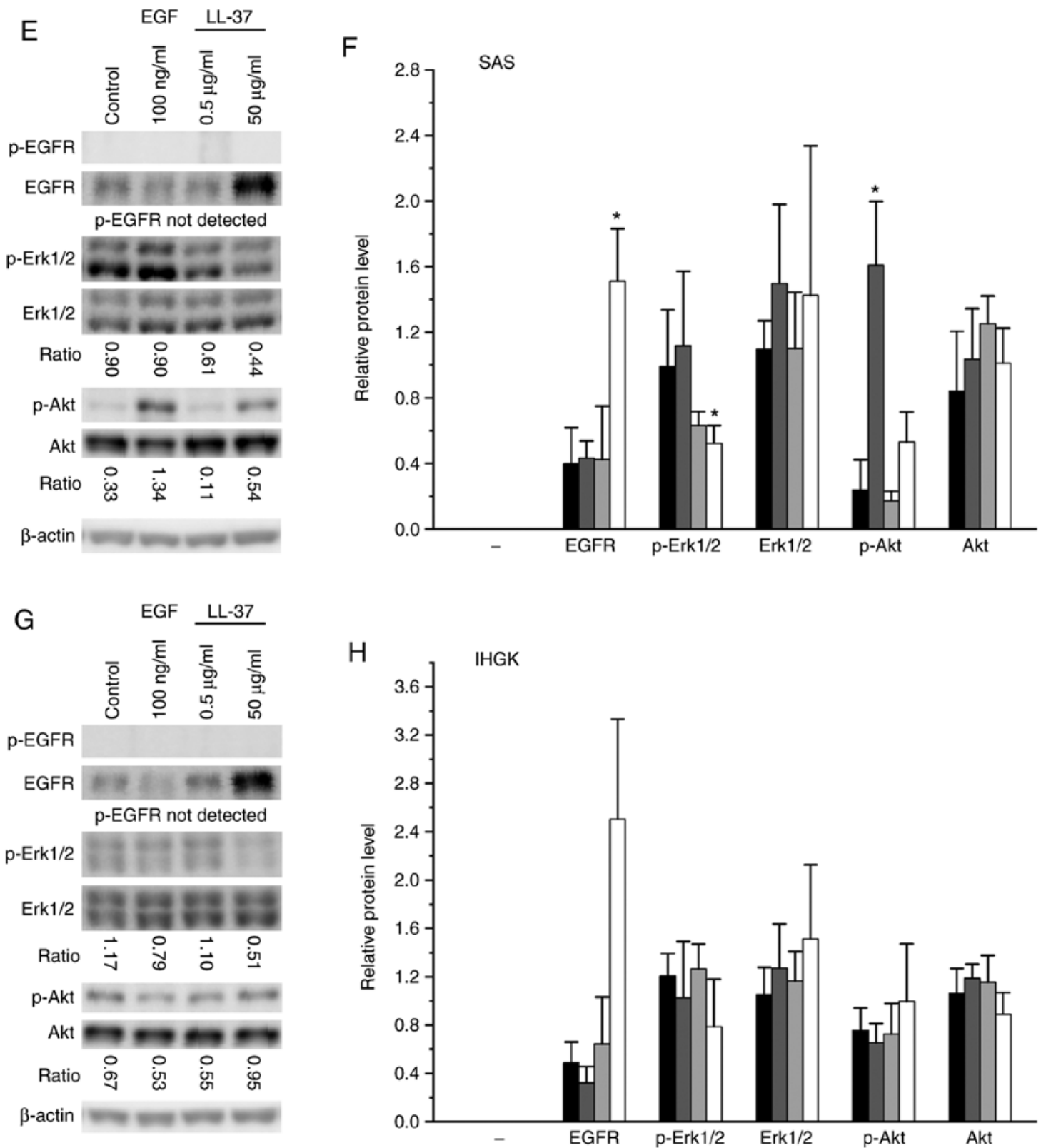

Figure 4. Continued. Immunoblot analysis of EGFR, Erk1/2 and Akt activation in EGF- or LL-37-treated OTSCC cell lines and IHGK cells. Cells were starved for $24 \mathrm{~h}$ and stimulated with the indicated doses of EGF or LL-37 for $1 \mathrm{~h}$. Starved non-stimulated cells were used as a control. Cell homogenates (30 $\mu \mathrm{g}$ of soluble protein) were separated on SDS-PAGE gels. The amounts of EGFR, Erk1/2 and Akt and their phosphorylated forms were analyzed with immunoblots in (E) SAS and (G) IHGK cells. In E and G, representative immunoblots are shown. The average ratio between the optical density of phosphorylated protein/total protein was calculated. $\beta$-actin was used as a control to normalize the quantities of proteins in (F) SAS and (H) IHGK cells using Fiji software. The results represent average \pm SD of two independent experiments, separated three times on SDS-PAGE gels. P-values were calculated with the independent-samples Kruskal-Wallis test and significance was adjusted by the Bonferroni correction for multiple tests. " $\mathrm{P}<0.05$, compared with the control. EGF, epidermal growth factor; EGFR, epidermal growth factor receptor; OTSCC, oral tongue squamous cell carcinoma; LL-37, antimicrobial peptide leucine-leucine-37.

metastasis and tumor progression promotion (21). Therefore, we analyzed the effect of recombinant LL-37 on one oral dysplastic and three oral tongue squamous cell carcinoma (OTSCC) cell lines and determined the expression of hCAP18/LL-37 in normal/dysplastic and OTSCC patient samples. Our data suggest that LL-37 has a fluctuating effect on proliferation and invasion of OTSCC cell lines, and the hCAP18/LL-37 levels are higher in normal/mild dysplastic samples of oral tongue when compared with levels in OTSCC samples.

All three OTSCC cell lines as well as the dysplastic IHGK cell line expressed hCAP18, the precursor form of
LL-37. Similarly, only the precursor has been detected in ovarian cancer cell lines (14); however, in HaCaT cells LL-37 was found also in the cell lysate (55). We also analyzed hCAP18/LL-37 from conditioned medium of one OTSCC cell line (data not shown), but we did not detect LL-37 nor hCAP18, which was also the case with HaCaT cells (55). In general, hCAP18 is considered to be cleaved extracellularly to LL-37 by proteinases $(11,12)$. In our case, however, it appeared that hCAP18/LL-37 were secreted in low levels or degraded rapidly after secretion, since they were not present in the conditioned medium of the OTSCC cell lines. The OTSCC cell lines seemed to produce different amounts of hCAP18, 
A

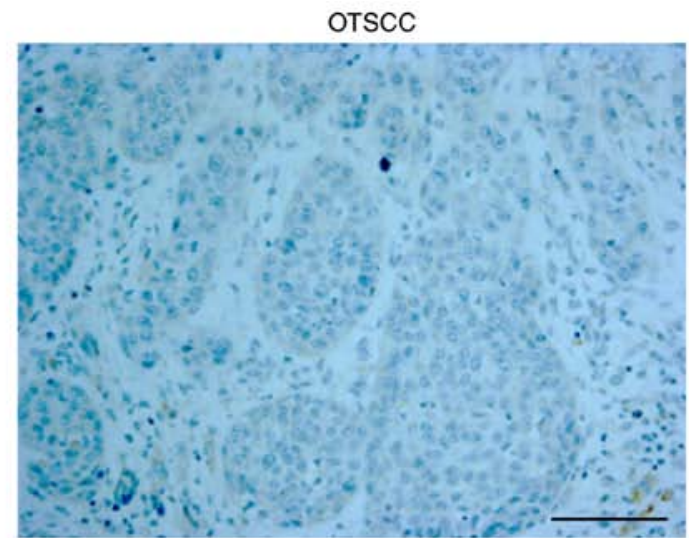

Negative LL-37 immunostaining

B

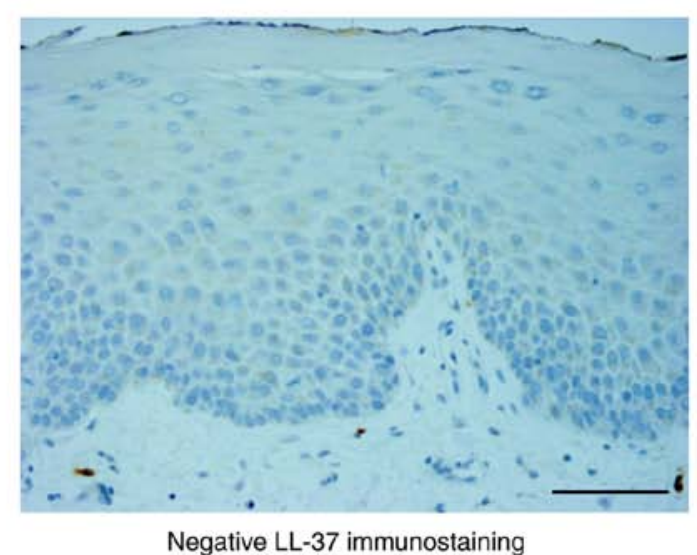

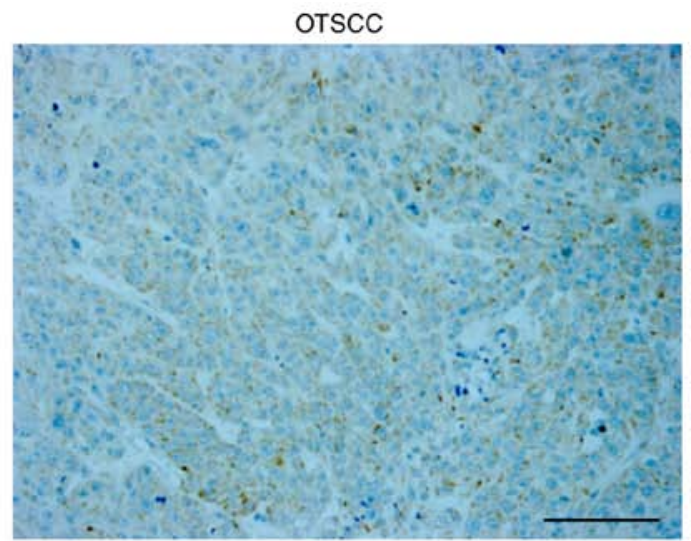

Positive LL-37 immunostaining

Dysplastic tissue

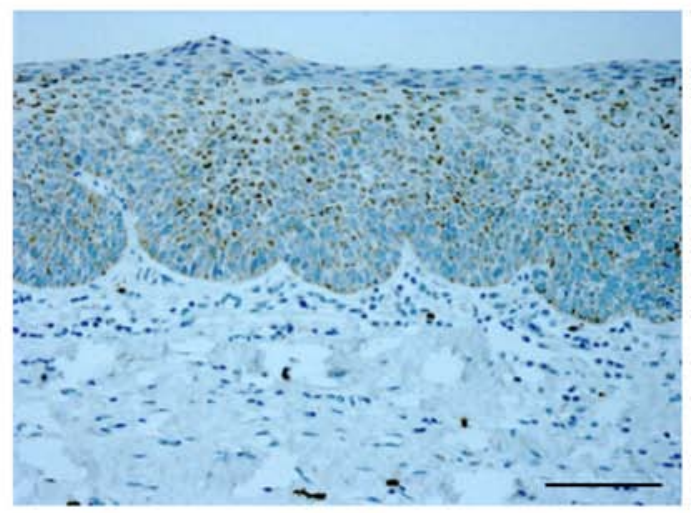

Positive LL-37 immunostaining

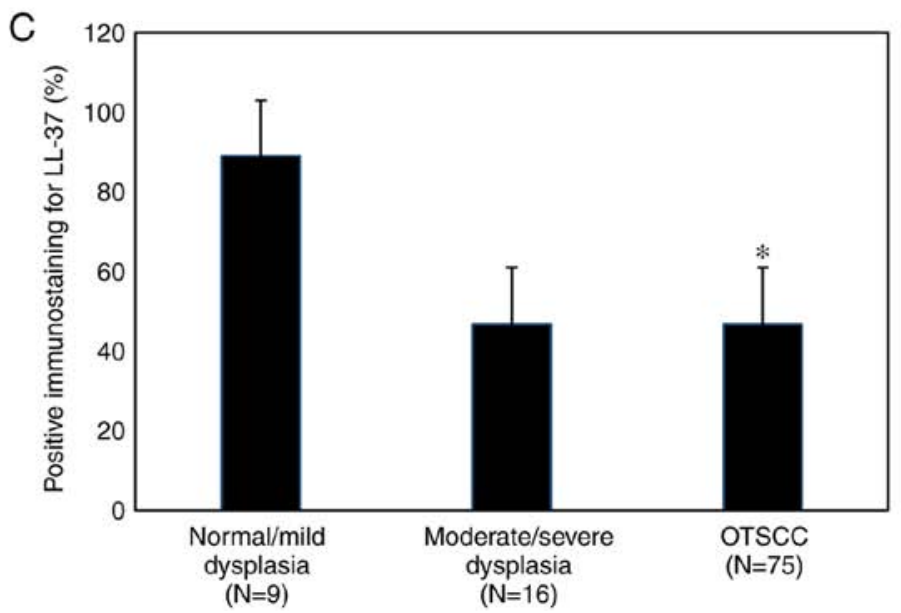

Figure 5. Expression of hCAP18/LL-37 in OTSCC and tongue dysplasia tissues. The expression of hCAP18/LL-37 was examined by immunohistochemistry. Representative images of hCAP18/LL-37 expression in (A) OTSCC and (B) dysplastic tongue tissue samples. Magnification x200; scale bar; $100 \mu \mathrm{m}$. (C) hCAP18/LL-37 expression was significant lower in OTSCC than in mild dysplasia $(\mathrm{P}<0.05)$. Additionally, expression of hCAP18/LL-37 was lower in moderate/severe dysplasia than in normal/mild dysplasia, but did not reach a significant level $(\mathrm{P}=0.059)$. Significant differences between groups was assessed by the Kruskal-Wallis test with Dunn's post hoc test. "P $\leq 0.05$, compared with mild dysplasia. OTSCC, oral tongue squamous cell carcinoma; hCAP18/LL-37, human host defense cationic antimicrobial peptide-18/antimicrobial peptide leucine-leucine-37.

while the SAS cell line had the highest endogenous protein amount of the three cancer cell lines tested. Lung cancer and malignant melanoma cell lines were also found to express varying amounts of hCAP18 $(15,16)$.

Our analysis revealed that a high dose $(50 \mu \mathrm{g} / \mathrm{ml})$ of recombinant LL-37 had a suppressive effect on the proliferation of OTSCC and dysplastic cell lines at early time points, which also leads to induced DNA fragmentation. Lower doses
$(0.5-10 \mu \mathrm{g} / \mathrm{ml})$ reduced the proliferation or had no considerable effects. In many cases, similar concentrations of LL-37 were previously found to induce the proliferation of cancer cells $(14-16,36-38,41,43)$. Nevertheless, in previous experiments higher concentrations of recombinant LL-37 $(>5-50 \mu \mathrm{g} / \mathrm{ml})$ seemed to decrease cell proliferation $(15,36-41,43)$ and even induce necrotic cell death (43) or caspase-independent apoptosis $(40,56)$. Furthermore, a truncated $(27-$ mer) peptide of 
Table III. Spearman correlation between immunohistochemical expression of hCAP18/LL-37 and clinicopathological variables.

hCAP18/LL-37

Variable (correlation coefficient/P-value)

\begin{tabular}{lc}
\hline Age & $-0.061 / 0.604$ \\
Sex & $0.025 / 0.829$ \\
Smoking habit & $0.129 / 0.397$ \\
T stage & $0.011 / 0.927$ \\
N stage & $0.099 / 0.446$ \\
Histopathological grade & $-0.018 / 0.882$ \\
Recurrence & $0.040 / 0.741$ \\
Treatment & $0.053 / 0.654$ \\
Neck dissection & $-0.123 / 0.296$ \\
\hline
\end{tabular}

hCAP18 was found to induce caspase-independent apoptosis of the highly invasive clone of SAS (42). In addition, a shortened fragment of LL-37, KI-21-3 caused considerable anti-proliferative and caspase-3-dependent apoptotic properties on SCC-4 cells (57). Interestingly, OTSCC cell lines responded somewhat differently to the LL-37 treatments after longer incubation. Especially with the SAS cell line, which had the highest cellular hCAP18 amount, the LL-37 peptide first markedly reduced proliferation, but then the effect was reversed and proliferation significantly increased. Regarding colon cancer cell lines, LL-37 was suggested to have different cytotoxicity towards p53 wild-type cells than towards p53-mutant cells (40). This finding could also partly explain our result since HSC-3 and SCC- 25 have been reported to carry p53 mutations $(58,59)$, while the SAS cell line has wild-type p53 $(60,61)$. However, our results suggest that LL-37 has a fluctuating reducing effect on proliferation of OTSCC cell lines.

Although LL-37 decreased cell proliferation of OTSCC cells, our experiments indicate that the peptide could induce cell migration and invasion. The cell lines tested are considered to exhibit varying ability to migrate and invade, HSC-3 and SAS being more aggressive than SCC-25 (45-49). As expected, the migration and invasion ability of aggressive OTSCC cell lines was significantly induced by our positive control EGF (62). In addition, all cell lines showed slightly increased migration and invasion with a low dose of LL-37, and the effect on invasion was pronounced with a high dose in SAS cells, which also have a high endogenous amount of hCAP18. Our results are concordant with earlier results showing that LL-37 promotes cancer cell motility $(14,16,18,25,36-38,43)$. Nevertheless, the OTSCC cell lines had a fluctuating response to the LL-37 peptide and the effect seemed not to fully correlate with the aggressiveness of the cell line.

LL-37 has been shown to transactivate EGFR in various epithelial cells and also in lung cancer cells $(15,26,27,43,50)$ in a process that involves stimulation of a membrane-anchored metalloproteinase, thereby releasing EGFR ligands $(26,27,50)$. In our experiments, we did not find EGFR phosphorylation with all of our epithelial origin cell lines even with positive control EGF. Surprisingly, in all cell lines the high dose of LL-37 increased the amount of total EGFR. Further analysis revealed that this increase was probably due to stabilization of the receptor to the plasma membrane. Others have reported that the total EGFR amount is unaffected by LL-37 treatment (27), and therefore, this is a new effect seen with LL-37.

Phosphorylation of Erk1/2, which is the key regulator of cell growth and cell cycle progression (63), decreased with the high dose of LL-37 in our studies, consistent with the proliferation results. In addition, activation of Akt, a master regulator of many metastatic processes, including cell growth, proliferation, motility and epithelial mesenchymal transition (EMT) (64), in most cases decreased with LL-37 treatment. However, in SAS cells the high dose of LL-37 induced Akt activation, which would explain the induced invasion of SAS cells. In previous studies, LL-37 has been shown to activate Erk1/2 or other MAP kinase pathways $(15,26,50,53)$ and Akt $(41,50,53,65)$. Furthermore, in these studies activation was linked to increased cell growth and/or motility $(15,41,50,53)$. LL-37 also affected the activation of these pathways in our cell lines, thereby changing their behavior. In addition, the amount of MMP2 and MMP9 was induced in OTSCC and dysplastic cell lines, but this increase was not directly associated with cell invasion, differing from earlier results $(14,53)$. Our results also suggest that LL-37 does not induce pronounced EMT in OTSCC cell lines. Previous findings concerning impact of LL-37 on EMT markers have been contradictory $(18,52)$, suggesting that LL-37 actions fluctuate depending on the cell line.

The in vitro results encouraged us to evaluate the immunoexpression and prognostic value of hCAP18/LL-37 in OTSCC patient samples and in oral tongue dysplasia. In the present study, we found that hCAP18/LL-37 expression was significantly lower in OTSCC tissues when compared with that in normal/mild dysplasia samples. Additionally, moderate/severe dysplasia showed lower expression of hCAP18/LL-37 than mild dysplasia, although the difference was not significant. This is in accordance with an earlier study showing that hCAP18/LL-37 is downregulated in oral cancer (21). Furthermore, in gastric and colon cancers the expression of hCAP18/LL-37 was previously found to be lower in cancer cells than in normal epithelium $(6,19,40,41)$. For these cancer cell line types, the hCAP18/LL-37 peptide had also a decreasing effect on cell proliferation $(39,41)$, as was mostly observed with our OTSCC cell lines. In a previous study, low hCAP18/LL-37 expression was associated with lymph node metastasis and tumor progression in OTSCC (21). However, with the limitations imposed by sample size, our observations suggest no correlation between cancer progression and/or patient outcome and expression of hCAP18/LL-37, even though hCAP18/LL-37 may have a suppressive effect on dysplasia and SCC in oral tongue epithelium.

This study has potential limitations. The effects of recombinant LL-37 were analyzed using only three OTSCC cell lines. However due to the unavailability of resources we were not able to include more cell lines to our experiments. Use of additional cell lines would have strengthened our conclusions concerning the main effects of LL-37 on OTSCC cell proliferation, migration/invasion and activation of the EGFR and its downstream pathways. In the analysis 
of the OTSCC patient samples, the sample number and the lack of complete data of all prominent confounding factors, resulted in limitations to the statistical analysis. In addition, the Kaplan-Meier analysis found that there were no differences between the positive and negative hCAP18/LL-37 groups. Thereby we were not able to perform multivariate analysis creating hazard ratios. Furthermore, the Spearman's rank correlation was used to calculate correlation between immunohistochemical expression of hCAP18/LL-37 and clinicopathological variables, since in our data the variables were not normally distributed.

In summary, we demonstrated that the LL-37 peptide reduced proliferation, and induced migration and invasion and MMP2 and MMP9 expression of OTSCC cell lines time- and cell line-dependently. In all cell lines, a high dose of LL-37 increased the amount of total EGFR. Furthermore, hCAP18/LL-37 immunoexpression was lower in OTSCC samples than that in the normal/mild tongue dysplasia, but expression did not correlate with patient outcome.

\section{Acknowledgements}

We gratefully acknowledge Maija-Leena Lehtonen, Tanja Kuusisto, Eeva-Maija Kiljander and Piia Mäkelä from University of Oulu for expert technical assistance.

\section{Funding}

The present study was supported by research grants from the Bayer Foundation, the Sigrid Juselius Foundation, the Cancer Foundation of Finland, the Medical Research Center Oulu, and research funds from the Medical Faculty of the University of Oulu and Oulu University Hospital special state support for research.

\section{Availability of data and materials}

The datasets used during the present study are available from the corresponding author upon reasonable request.

\section{Authors' contributions}

MV and MR conceived and designed the experiments, performed the experiments, analyzed the data and wrote the paper. PCR conceived and designed the experiments, analyzed the data and wrote the paper. ES and MS contributed materials, analyzed the data and wrote the paper. TS conceived and designed the experiments, contributed reagents and wrote the paper. All authors read and approved the manuscript and agree to be accountable for all aspects of the research in ensuring that the accuracy or integrity of any part of the work are appropriately investigated and resolved.

\section{Ethics approval and consent to participate}

This retrospective study was approved by the Ethics Committee of the Northern Ostrobothnia Hospital District, Finland (49/2010, 56/2010, 46/2013) and the Finnish National Supervisory Authority for Welfare and Health (6865/05.01.00.06/2010, 7449/06.01.03.01/2013).

\section{Patient consent for publication}

Not applicable.

\section{Competing interests}

All authors declare that there are no competing interests, and no financial or personal relationships with other people or organizations that could inappropriately influence this work.

\section{References}

1. Annertz K, Anderson H, Palmér K and Wennerberg J: The increase in incidence of cancer of the tongue in the Nordic countries continues into the twenty-first century. Acta Otolaryngol 132: 552-557, 2012.

2. Patel SC, Carpenter WR, Tyree S, Couch ME, Weissler M, Hackman T, Hayes DN, Shores C and Chera BS: Increasing incidence of oral tongue squamous cell carcinoma in young white women, age 18 to 44 years. J Clin Oncol 29: 1488-1494, 2011.

3. Ng JH, Iyer NG, Tan MH and Edgren G: Changing epidemiology of oral squamous cell carcinoma of the tongue: A global study. Head Neck 39: 297-304, 2017.

4. Bray F, Ferlay J, Soerjomataram I, Siegel RL, Torre LA and Jemal A: Global cancer statistics 2018: GLOBOCAN estimates of incidence and mortality worldwide for 36 cancers in 185 countries. CA Cancer J Clin 68: 394-424, 2018.

5. Mroueh R, Haapaniemi A, Grénman R, Laranne J, Pukkila M, Almangush A, Salo T and Mäkitie A: Improved outcomes with oral tongue squamous cell carcinoma in Finland. Head Neck 39: 1306-1312, 2017.

6. Wu WK, Wang G, Coffelt SB, Betancourt AM, Lee CW, Fan D, Wu K, Yu J, Sung JJ and Cho CH: Emerging roles of the host defense peptide LL-37 in human cancer and its potential therapeutic applications. Int J Cancer 127: 1741-1747, 2010.

7. Piktel E, Niemirowicz K, Wnorowska U, Watek M, Wollny T, Głuszek K, Góźdź S, Levental I and Bucki R: The role of cathelicidin LL-37 in cancer development. Arch Immunol Ther Exp (Warsz) 64: 33-46, 2016.

8. Xhindoli D, Pacor S, Benincasa M, Scocchi M, Gennaro R and Tossi A: The human cathelicidin LL-37-A pore-forming antibacterial peptide and host-cell modulator. Biochim Biophys Acta 1858: 546-566, 2016.

9. Kuroda K, Okumura K, Isogai $\mathrm{H}$ and Isogai E: The human cathelicidin antimicrobial peptide LL-37 and mimics are potential anticancer drugs. Front Oncol 5: 144, 2015.

10. Verjans ET, Zels S, Luyten W, Landuyt B and Schoofs L: Molecular mechanisms of LL-37-induced receptor activation: An overview. Peptides 85: 16-26, 2016.

11. Sørensen OE, Follin P, Johnsen AH, Calafat J, Tjabringa GS, Hiemstra PS and Borregaard N: Human cathelicidin, hCAP-18, is processed to the antimicrobial peptide LL-37 by extracellular cleavage with proteinase 3. Blood 97: 3951-3959, 2001.

12. Yamasaki K, Schauber J, Coda A, Lin H, Dorschner RA, Schechter NM, Bonnart C, Descargues P, Hovnanian A and Gallo RL: Kallikrein-mediated proteolysis regulates the antimicrobial effects of cathelicidins in skin. FASEB J 20: 2068-2080, 2006.

13. Heilborn JD, Nilsson MF, Jimenez CIC, Sandstedt B, Borregaard N, Tham E, Sørensen $\mathrm{OE}$, Weber G and Ståhle M: Antimicrobial protein hCAP18/LL-37 is highly expressed in breast cancer and is a putative growth factor for epithelial cells. Int J Cancer 114: 713-719, 2005.

14. Coffelt SB, Waterman RS, Florez L, Höner zu Bentrup K, Zwezdaryk KJ, Tomchuck SL, LaMarca HL, Danka ES, Morris CA and Scandurro AB: Ovarian cancers overexpress the antimicrobial protein hCAP-18 and its derivative LL-37 increases ovarian cancer cell proliferation and invasion. Int J Cancer 122: 1030-1039, 2008

15. von Haussen J, Koczulla R, Shaykhiev R, Herr C, Pinkenburg O, Reimer D, Wiewrodt R, Biesterfeld S, Aigner A, Czubayko F and Bals R: The host defence peptide LL-37/hCAP-18 is a growth factor for lung cancer cells. Lung Cancer 59: 12-23, 2008. 
16. Kim JE, Kim HJ, Choi JM, Lee KH, Kim TY, Cho BK, Jung JY, Chung KY, Cho D and Park HJ: The antimicrobial peptide human cationic antimicrobial protein-18/cathelicidin LL-37 as a putative growth factor for malignant melanoma. Br J Dermatol 163 : 959-967, 2010.

17. Hensel JA, Chanda D, Kumar S, Sawant A, Grizzle WE, Siegal GP and Ponnazhagan S: LL-37 as a therapeutic target for late stage prostate cancer. Prostate 71: 659-670, 2011.

18. Sainz B Jr, Alcala S, Garcia E, Sanchez-Ripoll Y, Azevedo MM, Cioffi M, Tatari M, Miranda-Lorenzo I, Hidalgo M, Gomez-Lopez G, et al: Microenvironmental hCAP-18/LL-37 promotes pancreatic ductal adenocarcinoma by activating its cancer stem cell compartment. Gut 64: 1921-1935, 2015.

19. Hase K, Murakami M, Iimura M, Cole SP, Horibe Y, Ohtake T, Obonyo M, Gallo RL, Eckmann L and Kagnoff MF: Expression of LL-37 by human gastric epithelial cells as a potential host defense mechanism against Helicobacter pylori. Gastroenterology 125: $1613-1625,2003$

20. An LL, Ma XT, Yang YH, Lin YM, Song YH and Wu KF: Marked reduction of LL-37/hCAP-18, an antimicrobial peptide, in patients with acute myeloid leukemia. Int J Hematol 81: 45-47, 2005

21. Chen X, Qi G, Qin M, Zou Y, Zhong K, Tang Y, Guo Y, Jiang X, Liang L and Zou X: DNA methylation directly downregulates human cathelicidin antimicrobial peptide gene (CAMP) promoter activity. Oncotarget 8: 27943-27952, 2017.

22. Coffelt SB, Tomchuck SL, Zwezdaryk KJ, Danka ES and Scandurro AB: Leucine leucine-37 uses formyl peptide receptor-like 1 to activate signal transduction pathways, stimulate oncogenic gene expression, and enhance the invasiveness of ovarian cancer cells. Mol Cancer Res 7: 907-915, 2009.

23. Li Y, Cai L, Wang H, Wu P, Gu W, Chen Y, Hao H, Tang K, Yi P, Liu M, et al: Pleiotropic regulation of macrophage polarization and tumorigenesis by formyl peptide receptor-2. Oncogene 30 : 3887-3899, 2011

24. De Yang D, Chen Q, Schmidt AP, Anderson GM, Wang JM Wooters J, Oppenheim JJ and Chertov O: LL-37, the neutrophi granule- and epithelial cell-derived cathelicidin, utilizes formyl peptide receptor-like 1 (FPRL1) as a receptor to chemoattract human peripheral blood neutrophils, monocytes, and T cells. J Exp Med 192: 1069-1074, 2000.

25. Weber G, Chamorro CI, Granath F, Liljegren A, Zreika S, Saidak Z, Sandstedt B, Rotstein S, Mentaverri R, Sánchez F, et al: Human antimicrobial protein hCAP18/LL-37 promotes a metastatic phenotype in breast cancer. Breast Cancer Res 11: R6, 2009.

26. Tjabringa GS, Aarbiou J, Ninaber DK, Drijfhout JW, Sørensen OE, Borregaard N, Rabe KF and Hiemstra PS: The antimicrobial peptide LL-37 activates innate immunity at the airway epithelial surface by transactivation of the epidermal growth factor receptor. J Immunol 171: 6690-6696, 2003.

27. Tokumaru S, Sayama K, Shirakata Y, Komatsuzawa H, Ouhara K, Hanakawa Y, Yahata Y, Dai X, Tohyama M, Nagai H, et al Induction of keratinocyte migration via transactivation of the epidermal growth factor receptor by the antimicrobial peptide LL-37. J Immunol 175: 4662-4668, 2005.

28. Frohm Nilsson M, Sandstedt B, Sørensen O, Weber G Borregaard N and Ståhle-Bäckdahl M: The human cationic antimicrobial protein (hCAP18), a peptide antibiotic, is widely expressed in human squamous epithelia and colocalizes with interleukin-6. Infect Immun 67: 2561-2566, 1999.

29. Khurshid Z, Naseem M, Yahya I Asiri F, Mali M, Sannam Khan R, Sahibzada HA, Zafar MS, Faraz Moin S and Khan E: Significance and diagnostic role of antimicrobial cathelicidins (LL-37) peptides in oral health. Biomolecules 7: pii: E80, 2017.

30. Oda D, Bigler L, Mao EJ and Disteche CM: Chromosomal abnormalities in HPV-16-immortalized oral epithelial cells. Carcinogenesis 17: 2003-2008, 1996.

31. Salo T, Sutinen M, Hoque Apu E, Sundquist E, Cervigne NK, de Oliveira CE, Akram SU, Ohlmeier S, Suomi F, Eklund L, et al: A novel human leiomyoma tissue derived matrix for cell culture studies. BMC Cancer 15: 981, 2015.

32. Salo T, Dourado MR, Sundquist E, Apu EH, Alahuhta I, Tuomainen K, Vasara J and Al-Samadi A: Organotypic three-dimensional assays based on human leiomyoma-derived matrices. Philos Trans R Soc Lond B Biol Sci 373: pii: 20160482, 2018.

33. Schindelin J, Arganda-Carreras I, Frise E, Kaynig V, Longair M, Pietzsch T, Preibisch S, Rueden C, Saalfeld S, Schmid B, et al: Fiji: An open-source platform for biological-image analysis. Nat Methods 9: 676-682,2012.
34. Nyberg P, Heikkilä P, Sorsa T, Luostarinen J, Heljasvaara R, Stenman UH, Pihlajaniemi T and Salo T: Endostatin inhibits human tongue carcinoma cell invasion and intravasation and blocks the activation of matrix metalloprotease-2, -9 , and -13 . J Biol Chem 278: 22404-22411, 2003.

35. Sundquist E, Kauppila JH, Veijola J, Mroueh R, Lehenkari P, Laitinen S, Risteli J, Soini Y,Kosma VM, Sawazaki-Calone I, et al: Tenascin-C and fibronectin expression divide early stage tongue cancer into low- and high-risk groups. Br J Cancer 116: 640-648, 2017.

36. Wang W, Zheng Y, Jia J, Li C, Duan Q, Li R, Wang X, Shao Y, Chen $\mathrm{C}$ and Yan H: Antimicrobial peptide LL-37 promotes the viability and invasion of skin squamous cell carcinoma by upregulating YB-1. Exp Ther Med 14: 499-506, 2017.

37. Wang W, Jia J, Li C, Duan Q, Yang J, Wang X, Li R, Chen C, Yan $\mathrm{H}$ and Zheng Y: Antimicrobial peptide LL-37 promotes the proliferation and invasion of skin squamous cell carcinoma by upregulating DNA-binding protein A. Oncol Lett 12: 1745-1752, 2016.

38. Jia J, Zheng Y, Wang W, Shao Y, Li Z, Wang Q, Wang Y and Yan H: Antimicrobial peptide LL-37 promotes YB-1 expression, and the viability, migration and invasion of malignant melanoma cells. Mol Med Rep 15: 240-248, 2017.

39. Wu WK, Sung JJ, To KF, Yu L, Li HT, Li ZJ, Chu KM, Yu J and Cho CH: The host defense peptide LL-37 activates the tumor-suppressing bone morphogenetic protein signaling via inhibition of proteasome in gastric cancer cells. J Cell Physiol 223: 178-186, 2010

40. Ren SX, Cheng AS, To KF, Tong JH, Li MS, Shen J, Wong CC, Zhang L, Chan RL, Wang XJ, et al: Host immune defense peptide LL-37 activates caspase-independent apoptosis and suppresses colon cancer. Cancer Res 72: 6512-6523, 2012.

41. Li D, Liu W, Wang X, Wu J, Quan W, Yao Y, Bals R, Ji S, Wu K, Guo J and Wan H: Cathelicidin, an antimicrobial peptide produced by macrophages, promotes colon cancer by activating the $\mathrm{Wnt} / \beta$-catenin pathway. Oncotarget 6 : 2939-2950, 2015.

42. Okumura K, Itoh A, Isogai E, Hirose K, Hosokawa Y, Abiko Y, Shibata T, Hirata $\mathrm{M}$ and Isogai $\mathrm{H}$ : C-terminal domain of human CAP18 antimicrobial peptide induces apoptosis in oral squamous cell carcinoma SAS-H1 cells. Cancer Lett 212: 185-194, 2004.

43. Shaykhiev R, Beisswenger C, Kändler K, Senske J, Püchner A, Damm T, Behr J and Bals R: Human endogenous antibiotic LL-37 stimulates airway epithelial cell proliferation and wound closure. Am J Physiol Lung Cell Mol Physiol 289: L842-L848, 2005.

44. Kamata N, Chida K, Rikimaru K, Horikoshi M, Enomoto S and Kuroki T: Growth-inhibitory effects of epidermal growth factor and overexpression of its receptors on human squamous cell carcinomas in culture. Cancer Res 46: 1648-1653, 1986.

45. Momose F, Araida T, Negishi A, Ichijo H, Shioda S and Sasaki S: Variant sublines with different metastatic potentials selected in nude mice from human oral squamous cell carcinomas. J Oral Pathol Med 18: 391-395, 1989.

46. Matsumoto K, Matsumoto K, Nakamura T and Kramer RH: Hepatocyte growth factor/scatter factor induces tyrosine phosphorylation of focal adhesion kinase (p125FAK) and promotes migration and invasion by oral squamous cell carcinoma cells. J Biol Chem 269: 31807-31813, 1994

47. Ramos DM, Chen BL, Boylen K, Stern M, Kramer RH, Sheppard D, Nishimura SL, Greenspan D, Zardi L and Pytela R: Stromal fibroblasts influence oral squamous-cell carcinoma cell interactions with tenascin-C. Int J Cancer 72: 369-376, 1997.

48. Okumura K, Konishi A, Tanaka M, Kanazawa M, Kogawa K and Niitsu Y: Establishment of high- and low-invasion clones derived for a human tongue squamous-cell carcinoma cell line SAS. J Cancer Res Clin Oncol 122: 243-248, 1996.

49. Takahashi K, Kanazawa H, Akiyama Y, Tazaki S, Takahara M, Muto T, Tanzawa H, Sato KI, Akiyama T, MUTO T, et al: Establishment and characterization of a cell line (SAS) from poorly differentiated human squamous cell carcinoma of the tongue. J Jpn Stomatol Soc 38: 20-28, 1989.

50. Yin J and Yu FS: LL-37 via EGFR transactivation to promote high glucose-attenuated epithelial wound healing in organ-cultured corneas. Invest Ophthalmol Vis Sci 51: 1891-1897, 2010.

51. Ribeiro FA, Noguti J, Oshima CT and Ribeiro DA: Effective targeting of the epidermal growth factor receptor (EGFR) for treating oral cancer: A promising approach. Anticancer Res 34: $1547-1552,2014$ 
52. Cheng M, Ho S, Yoo JH, Tran DH, Bakirtzi K, Su B, Tran DH, Kubota Y, Ichikawa R and Koon HW: Cathelicidin suppresses colon cancer development by inhibition of cancer associated fibroblasts. Clin Exp Gastroenterol 8: 13-29, 2014.

53. Carretero M, Escámez MJ, García M, Duarte B, Holguín A, Retamosa L, Jorcano JL, Río MD and Larcher F: In vitro and in vivo wound healing-promoting activities of human cathelicidin LL-37. J Invest Dermatol 128: 223-236, 2008.

54. Smith A, Teknos TN and Pan Q: Epithelial to mesenchymal transition in head and neck squamous cell carcinoma. Oral Oncol 49: 287-292, 2013.

55. Braff MH, Di Nardo A and Gallo RL: Keratinocytes store the antimicrobial peptide cathelicidin in lamellar bodies. J Invest Dermatol 124: 394-400, 2005.

56. Mader JS, Mookherjee N, Hancock REW and Bleackley RC: The human host defense peptide LL-37 induces apoptosis in a calpain- and apoptosis-inducing factor-dependent manner involving Bax activity. Mol Cancer Res 7: 689-702, 2009.

57. Açil Y, Torz K, Gülses A, Wieker H, Gerle M, Purcz N Will OM, Eduard Meyer J and Wiltfang J: An experimental study on antitumoral effects of KI-21-3, a synthetic fragment of antimicrobial peptide LL-37, on oral squamous cell carcinoma. J Craniomaxillofac Surg 46: 1586-1592, 2018.

58. Sakai E and Tsuchida N: Most human squamous cell carcinomas in the oral cavity contain mutated p53 tumor-suppressor genes. Oncogene 7: 927-933, 1992.
59. Min BM, Baek JH, Shin KH, Gujuluva CN, Cherrick HM and Park NH: Inactivation of the p53 gene by either mutation or HPV infection is extremely frequent in human oral squamous cell carcinoma cell lines. Eur J Cancer B Oral Oncol 30B: 338-345, 1994.

60. Kanata H, Yane K, Ota I, Miyahara H, Matsunaga T, Takahashi A, Ohnishi K, Ohnishi T and Hosoi H: CDDP induces p53-dependent apoptosis in tongue cancer cells. Int J Oncol 17: 513-517, 2000.

61. Ohnishi K, Ota I, Takahashi A and Ohnishi T: Glycerol restores p53-dependent radiosensitivity of human head and neck cancer cells bearing mutant p53. Br J Cancer 83: 1735-1739, 2000.

62. Ratushny V, Astsaturov I, Burtness BA, Golemis EA and Silverman JS: Targeting EGFR resistance networks in head and neck cancer. Cell Signal 21: 1255-1268, 2009.

63. Meloche S and Pouysségur J: The ERK1/2 mitogen-activated protein kinase pathway as a master regulator of the G1- to S-phase transition. Oncogene 26: 3227-3239, 2007.

64. Qiao M, Sheng S and Pardee AB: Metastasis and AKT activation. Cell Cycle 7: 2991-2996, 2008.

65. Nijnik A, Pistolic J, Filewod NCJ and Hancock REW: Signaling pathways mediating chemokine induction in keratinocytes by cathelicidin LL-37 and flagellin. J Innate Immun 4: 377-386, 2012. 